\title{
ISOLASI DYE ORGANIK ALAM DAN KARAKTERISASINYA SEBAGAI SENSITIZER
}

\author{
Nurussaniah $^{1)}$, Anita $^{2)}$, Boisandi $^{3)}$ \\ 1) IKIP PGRI Pontianak, Pontianak, Indonesia \\ E-mail: nurussaniah@gmail.com \\ 2) IKIP PGRI Pontianak, Pontianak, Indonesia \\ E-mail: anitaummufaqih@gmail.com \\ 3) IKIP PGRI Pontianak, Pontianak, Indonesia \\ E-mail: bsandi2012@gmail.com
}

\begin{abstract}
Abstrak. Tujuan penelitian ini adalah untuk mengetahui cara mengisolasi dan karakteristik dye organik alam sebagai sensitizer. Penelitian ini dilakukan melalui beberapa tahap yaitu persiapan, isolasi dye organik alam, karakterisasi sifat optik, analisis dan menyimpulkan. Isolasi dye organic alam dilakukan untuk memperoleh sari dari bahan-bahan alam. Penelitian ini menggunakan bahan alam yaitu jagung (Zea mays) dan labu kuning (Cucurbita moschata). Karakterisasi optik dye organik alam dalam penelitian ini dilihat dari spektrum absorbansi yang diukur menggunakan Spektrophotometer Uv-Vis. Spektrum absorbansi dye diukur dalam kuvet optik, pada panjang gelombang 350-800 $\mathrm{nm}$. Hasil penelitian menunjukkan bahwa isolasi dye organik alam diperoleh melalui metode ekstraksi, yaitu suatu metode untuk memperoleh sari dari bahan-bahan alam. Proses ekstraksi dilakukan dengan melarutkan biji jagung (Zea mays) dan daging buah labu kuning (Cucurbita moschata) dalam pelarut etanol dengan konsentrasi 1:5. Karaktistik optik jagung (Zea mays) dan labu kuning (Cucurbita moschata) menunjukkan panjang gelombang yaitu berada pada cahaya tampak dengan rentang panjang gelombang $350-500 \mathrm{~nm}$. Dengan demikian dye beta-karoten yang berasal dari jagung (Zea mays) dan labu kuning (Cucurbita moschata) dapat dimanfaatkan sebagai sensitizer dalam prototipe Dye Sensitized Solar Cell (DSSC).
\end{abstract}

Kata Kunci: Dye; Jagung (Zea Mays); Labu Kuning (Cucurbita Moschata); Sensitizer

\section{Pendahuluan}

Sel surya salah satu alternatif sumber energi yang ramah akan lingkungan. Hal ini dikarenakan bahan yang digunakan tergolong kepada energi yang terbaharukan. Jumlah bahan alam ini akan tersedia dan melimpah, tidak akan pernah habis selagi manusia terus melestarikannya. Hal ini sejalan dengan isu-isu yang sedang digalakkan oleh pemerhati lingkungan dalam rangka penyelamatan dunia oleh global warming.

Seiring perkembangan ilmu pengetahuan dan teknologi mendorong para ilmuan untuk menemukan alternatif pengganti sel surya silikon dengan sumber energi terbarukan dari alam. Telah banyak penelitian yang dilakukan untuk menemukan bahan yang dapat digunakan sebagai alternatif dalam menggantikan fungsi dari silikon dalam penggunakan piranti semikonduktor [1] [2]. Dye sensitized solar cells (DSSC) merupakan imitasi dari bagaimana proses pada tumbuhan memanfaatkan sinar matahari kemudian mengubahnya menjadi sebuah energi. Sel surya generasi ketiga tersebut, memanfaatkan efek fotoelektrokimia pada pewarnaan dalam sejumlah bahan khususnya pada bahan organik. Dengan demikian, efisiensi sel surya tersebut tergantung pada absorbansi dari sebuah bahan dalam menyerap cahaya serta transportasi elektron dari sebuah materi yang kemudian akan menghasilkan sumber energi listrik.

Penemuan yang baru pada fabrikasi dan karakterisasi pada bahan nanokristalin terjadi pada DSSC, di mana antara proses absorbsi dan separasi cahaya terjadi secara terpisah [3]. Absorbsi cahaya dilakukan oleh molekul dye dan separasi muatan listrik pada celah pita lebar semikonduktor nanokristalin [3]. Dye yang digunakan pada penelitian ini adalah beberapa bahan alami yang ada di alam (sekitar) yang diperoleh dari hasil proses ekstraksi. Beberapa dye yang dapat dijadikan sebagai DSSC adalah klorofil yang berasal dari tumbuh-tumbuhan yang berwarna hijau, betakaroten yang berasal dari tumbuhan yang dominan berwarna orange, dan berbagai jenis tumbuhan yang memiliki warna yang mencolok 


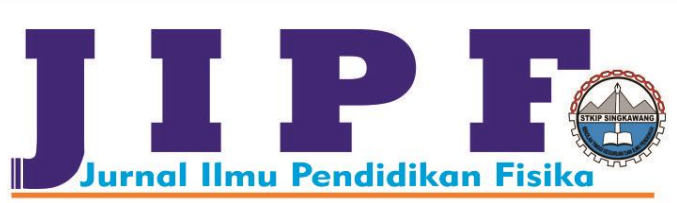

lainnya. Berdasarkan latar belakang tersebut maka penelitian ini mengkaji karakteristik dye organik alam yang nantinya dapat digunakan sebagai sensitizer.

\section{MetodE}

Penelitian ini merupakan penelitian eksperimen. Kegiatan penelitian meliputi isolasi dan karakterisasi sifat optik (spektrum absorbansi) dye organik alam. Dye organik alam yang digunakan dalam penelitian ini adalah jagung (Zea mays) dan labu kuning (Cucurbita moschata).

Alur penelitian secara ringkasi disajikan dalam bentuk diagram. Adapun diagram alir penelitian secara umum dapat dilihat pada Gambar 1.

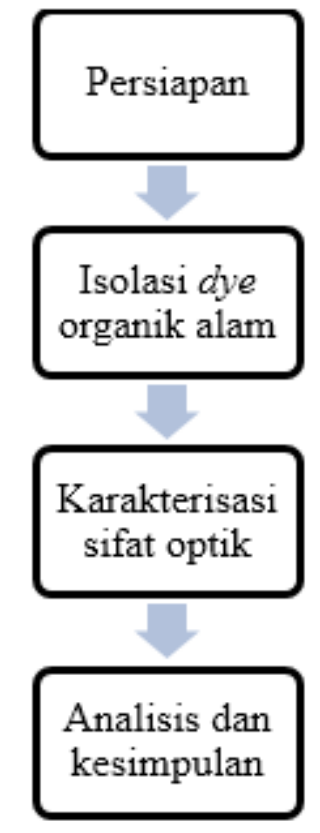

Gambar 1. Diagram Alir Penelitian

Persiapan penelitian meliputi persiapan alat dan bahan terutama membersihkan alat-alat eksperimen sebelum digunakan. Adapun alat dan bahan yang digunakan dalam penelitian ini adalah gelas beker, batang pengaduk, spatula, corong, pipet tetes, mortar dan pestle magnetic stirrer, kertas saring, botol gelap, alumunium foil, hotplate dan neraca digital. Sedangkan bahan yang digunakan dalam penelitian ini adalah jagung (Zea mays), labu kuning (Cucurbita moschata) dan etanol. Sebelum digunakan maka seluruh alat dibersihkan dengan mencuci menggunakan deterjen, kemudian dibersihkan menggunakan ultrasonic cleaner.

Penelitian menggunakan bahan alam untuk memperoleh dye organik alam. Isolasi dye organik alam diperoleh melalui metode ekstraksi, yaitu suatu metode untuk memperoleh sari dari bahan-bahan alam. Proses ekstraksi dilakukan dengan melarutkan biji jagung (Zea mays) dan daging buah labu kuning (Cucurbita moschata) dalam pelarut etanol dengan konsentrasi 1:5.

Karakterisasi optik dye organik alam dalam penelitian ini dilihat dari spektrum absorbansi yang diukur menggunakan
Jurnal Ilmu Pendidikan Fisika

Volume 3 Number 1 month March 2018. Page 24-27 p-ISSN: 2477-5959 e-ISSN: 2477-8451

Spektrophotometer Uv-Vis. Spektrum absorbansi dye diukur dalam kuvet optik, pada panjang gelombang 350-800 nm.

\section{HASIL DAN PEMBAHASAN}

Penelitian ini bertujuan untuk mengetahui cara mengisolasi dye organik alam sebagai sensitizer dan karakteristik optik dari dye organik alam tersebut. Dye organik alami yang digunakan adalah jagung (Zea mays) dan labu kuning (Cucurbita moschata). Isolasi dye organik alam diperoleh melalui metode ekstraksi, yaitu suatu metode untuk memperoleh sari dari bahan-bahan alam. Proses ekstraksi dilakukan dengan melarutkan biji jagung (Zea mays) dan daging buah labu kuning (Cucurbita moschata) dalam pelarut etanol dengan konsentrasi 1:5.

Setelah diperoleh larutan dye organik, kemudian di uji karakteristik optiknya atau nilai absorbansinya menggunakan Spektrophotometer Uv-Vis.

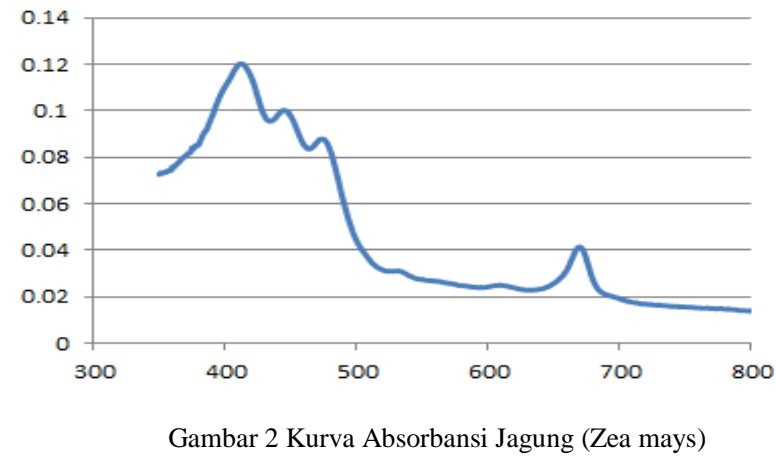

Gambar 2 merupakan kurva hasil pengukuran absorbansi jagung (Zea mays). Berdasarkan hasil pengukuran absorbansi, sifat optik jagung (Zea mays) berada pada panjang gelombang mulai dari dari $350 \mathrm{~nm}$ hingga $470 \mathrm{~nm}$ dengan puncak gelombang berada pada sekitar $450 \mathrm{~nm}$ dan pada panjang gelombang $650 \mathrm{~nm}$ hingga700 $\mathrm{nm}$ dengan puncak berada pada sekitar $680 \mathrm{~nm}$. Karena panjang gelombang jagung yang berada pada daerah cahaya tampak (visible light) maka jagung (Zea mays) merupakan salah satu bahan alam yang dapat digunakan sebagai sensitizer dan dapat digunakan sebagai material aktif dalam protipe (Dye Sensitizer Solar Cell) DSSC.

Gambar 3 merupakan kurva hasil pengukuran absorbansi labu kuning (Cucurbita moshata). Berdasarkan hasil pengukuran absorbansi, diketahui bahwa sifat optik labu kuning (Cucurbita moschata) berada pada panjang gelombang mulai dari dari $350 \mathrm{~nm}$ hingga $500 \mathrm{~nm}$ dengan puncak gelombang berada pada sekitar $450 \mathrm{~nm}$. Berdasarkan nilai absobansi tersebut, maka labu kuning (Cucurbita moschata berada pada daerah cahaya tampak (visible light). Oleh karena itu labu kuning (Cucurbita moschata) merupakan salah satu bahan alam yang dapat digunakan sebagai sensitizer dan dapat digunakan sebagai material aktif dalam protipe (Dye Sensitizer Solar Cell) DSSC. 

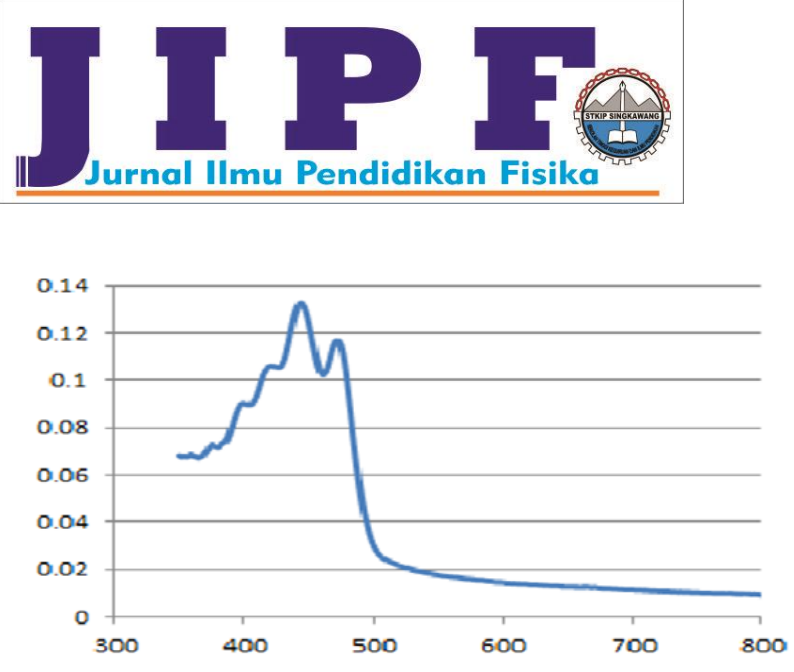

Gambar 3 Kurva Absorbansi Labu Kuning (Cucurbita moschata)

Pada Gambar 4, merupakan kurva hasil absorbansi dye antara labu kuning dan jagung dengan etanol sebagai pelarutnya. Pada gambar 4.3 terlihat bahwa absorbansi jagung (Zea mays) dan labu kuning (Cucurbita moschata) hampir berhimpit satu sama lain di sekitar panjang gelombang 450 $\mathrm{nm}$. Rentang panjang gelombang $350-500 \mathrm{~nm}$ merupakan rentang panjang gelombang cahaya tampak (visible light).

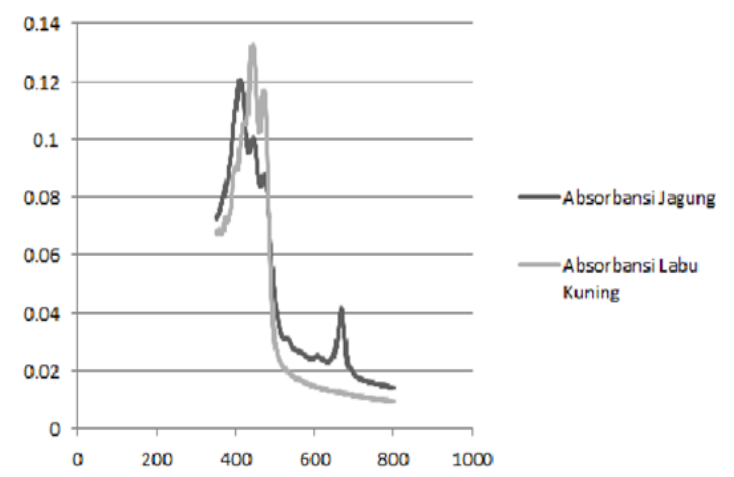

Gambar 4 Kurva absorbansi jagung (Zea mays) dan labu kuning (Cucurbita moschata)

Pada penelitian ini, jagung (Zea mays) dan labu kuning (Cucurbita moschata) di ekstraksi dengan perbandingan 1:5. Hasil ekstraksi dari jagung (Zea mays) dan labu kuning (Cucurbita moschata) dengan pelarut etanol menghasilkan larutan yang berwarna kuning (kekuning-kuningan). Dengan demikian jagung dan labu kuning merupakan bahan yang mengandung Beta-karoten [4] [5]. Hal ini dikarenakan Betakaroten terdapat pada setiap bagian tanaman yaitu dari bunga, buah, batang, dan akar serta memberikan pigmen pada buahbuahan dan bunga dengan khas warna merah, warna oranye dan kuning [6].

Penggunaaan etanol sebagai pelarut pada proses ekstraksi dikarenakan pemilihan pelarut yang tepat sangat menentukan isolasi beta-karoten. Suatu zat dapat larut dalam pelarut jika mempunyai nilai polaritas yang sama. Selain itu, pelarut yang baik adalah pelarut yang tidak merusak solut atau residu [7] [8]. Etanol termasuk pelarut polar dengan konstanta dielektrik 30 [9]. Hal ini menunjukkan penggunaan etanol sebagai
Jurnal Ilmu Pendidikan Fisika

Volume 3 Number 1 month March 2018. Page 24-27 p-ISSN: 2477-5959 e-ISSN: 2477-8451

pelarut pada proses isolasi jagung (Zea mays) dan labu kuning (Cucurbita moschata) telah tepat digunakan sehingga benarbenar dapat melarutkan biji jagung (Zea mays) dan daging labu kuning (Cucurbita moschata).

Hasil uji karakteristik optik diperoleh bahwa nilai absorbansi jagung dan labu kuning berada pada cahaya tampak dengan rentang panjang gelombang $350-500 \mathrm{~nm}$. Hal ini sesuai dengan Cuttriss dan Pogson (2004) yang menyatakan bahwa Beta-karoten menyerap spektrum cahaya tampak antara $380 \mathrm{~nm}$ dan $520 \mathrm{~nm}$.

Absorbansi sebuah dye merupakan penyerapan cahaya matahari yang mengandung energi foton oleh molekulmolekul dye yang mengandung elektron-elektron. Pada DSSC, Energi foton yang mengenai sebuah permukaan sel surya akan mengeksitasi elektron-elektron dari sebuah dye yang terserap pada bahan semikonduktor $\left(\mathrm{TiO}_{2}\right)$ pada pita valensi ke pita konduksi sehingga akan memunculkan arus listrik. Semakin kuat elektron-elektron yang terikat dalam molekul maka semakin besar pula nilai absorbansinya. Berdasarkan nilai absorbansi jagung dan labu kuning dapatkan disimpulkan bahwa jagung (Zea mays) dan labu kuning (Cucurbita moschata) dapat digunakan sebagai dye pada DSSC.

\section{KESIMPULAN}

Berdasarkan hasil penelitian dan pembahasan dapat ditarik kesimpulan yaitu isolasi dye organik alam diperoleh melalui metode ekstraksi, yaitu suatu metode untuk memperoleh sari dari bahan-bahan alam. Proses ekstraksi dilakukan dengan melarutkan biji jagung (Zea mays) dan daging buah labu kuning (Cucurbita moschata) dalam pelarut etanol dengan konsentrasi 1:5. Karaktistik optik jagung (Zea mays) dan labu kuning (Cucurbita moschata) menunjukkan panjang gelombang yaitu berada pada cahaya tampak dengan rentang panjang gelombang $350-500 \mathrm{~nm}$. Dengan demikian dye beta-karoten yang berasal dari jagung (Zea mays) dan labu kuning (Cucurbita moschata) dapat dimanfaatkan sebagai sensitizer dalam prototipe Dye Sensitized Solar Cell (DSSC). Dengan mengetahui karakteristik dye organik alam diharapkan nantinya akan dimanfaatkan sebagai sensitizer serta sebagai dasar dan acuan dalam penelitian selanjutnya dalam mengembangkan sel surya dengan lebih baik dan lebih efisien.

\section{UCAPAN TERIMAKASIH}

Kami ingin mengucapkan terima kasih kepada Lembaga Penelitian dan Pengabdian Kepada Masyrakat (LPPM) IKIP PGRI Pontianak yang telah mendanai penelitian dengan kontrak no 056/L.202-103/PDK/III/2017.

\section{DAFTAR PUSTAKA}

[1] Rosdianto, H., \& Toifur, M. (2017). Implementasi Teori Distribusi Probabilitas Gaussian Pada Kualitas Rangkaian Penyearah Gelombang Penuh. Spektra: Jurnal Fisika dan Aplikasinya, 2(1), 83-90.

[2] Rosdianto, H. (2017). Penentuan Percepatan Gravitasi Pada Percobaan Gerak Jatuh Bebas Dengan Memanfaatkan Rangkaian Relai. Spektra: Jurnal Fisika dan Aplikasinya, 2(2), 107-112. 
[3] Gratzel, M. 2003. Dye Sensitized Solar Cells. J. Of Photochemistry and Photobiology C: Photochemistry Reviews 4 pp. 145-153.

[4] Yasin HG. M, Rahman H., dan Santoso S B., 2010, Karakter "Obatanpa(Pro-A) BC1C2-F2 dan KUI Carotenoid.Syn" Calon Varietas Opv. Kaya Vitamin-A, Prosiding Pekan Serealia Nasional, 2010, ISBN : 978979-8940-29-3.

[5] Gardjito M., Murdiati A., Aini N., 2006, Mikroenkapsulasi $\beta$-karoten Buah Labu Kuning dengan Enkapsulan Whey dan Karbohidrat, Jurnal Teknologi Pertanian, 2(1): 13-18, Agustus 2006, ISSN 1858-2419.

[6] Cuttriss A., dan Pogson B., 2004, Carotenoids, dalam K. Davies (edt), Plant Pigments And Their Manipulation. USA: Blackwell Publishing (Ltd). Annual plant review, vol 14.

[7] Gao F. G., Bard A. J., Kispert L. D., 2000, Photocurrent generated on a carotenoid-sensitized $\mathrm{TiO} 2$ nanocrystalline mesoporous electrode, Journal of Photochemistry and Photobiology A: Chemistry, 130 (2000) 49-56.

[8] Adalid A.M., Rosello’ S., Nuez F., 2010, Evaluation and selection of tomato accessions (Solanum section Lycopersicon) for content of lycopene, b-carotene and ascorbic acid, Journal of Food Composition and Analysis, Elsevier, 23 (2010) 613-618.

[9] Lide Ed. CRC., 2004, Handbook of Chemistry and Physics, 85th Ed. CRC Press. Boca Raton. 